\title{
Chiral palladium complexes based on derivatives of benzylamine and $2 \alpha$-hydroxypinan-3-one
}

\author{
Olga A. Zalevskaya ${ }^{a}$, Yana A. Gur'eva ${ }^{b,{ }^{*}}$, Larisa L. Frolova ${ }^{b}$, Igor N. Alekseev ${ }^{b}$, Alexander V. \\ Kutchin ${ }^{\mathrm{b}}$
}

\footnotetext{
${ }^{a}$ Syktyvkar State University, Syktyvkar, Petrozavodskaja, Syktyvkar, Russia

${ }^{\mathrm{b}}$ Institute of Chemistry of Komi Scientific Centre, Ural Branch of Russian Academy of Sciences, Pervomaiskaja, Syktyvkar, Russia;

*Corresponding author: gurjeva-ja@,chemi.komisc.ru
}

Received 30 July 2010; revised 2 September 2010; accepted 5 September 2010.

\begin{abstract}
Synthesized and characterized new chiral palladium complexes, some of which contain asymmetric donor nitrogen atom. Nitrogen-containing derivatives (+) - and (-)-2a-hydroxypinan-3-one(1R,2R,5R)-3-(benzylimino)-2,6,6-trimethylbicyclo[3.1.1] heptane-2-ol $\left(\mathrm{HL}^{1}\right)$, (1S,2S,3S,5S)-3(benzylamino)-2,6, 6-trimethylbicyclo[3.1.1]heptane-2-ol ( $\left.\mathrm{HL}^{2}\right)$, (1R,2R,5R)-3-((S)- $\alpha$-methylbenzylimino)-2,6,6-trimethylbicyclo[3.1.1]heptane-2-ol ( $\left.\mathrm{HL}^{3}\right)$, (1R,2R,3R,5R)-3-((S)- $\alpha$-methylbenzylamino)-2,6,6-trimethylbicyclo[3.1.1]heptane-2-ol $\left(\mathrm{HL}^{4}\right)$-were studied as optically active ligands.
\end{abstract}

Keywords: Palladium Complexes; Cyclopalladation; Chiral Imine; Amine

\section{INTRODUCTION}

Chiral palladium complexes of various types are widely used in modern asymmetric synthesis, the goal of which is to obtain enantiopure compounds. Cyclopalladated complexes (CPCs) form a special group of compounds with a $\sigma$-connection palladium-carbon [1]. These complexes show reasonably high activity and thermal stability. Chiral CPCs are very successfully used in asymmetric synthesis, both as the original matrix [2-7] and as catalysts [8-12]. They have been used in NMR studies as shifting reagents [13-15] and as effective resolution agents [16-18]. This is especially significant for obtaining enantiopure phosphines, which are efficient ligands for asymmetric catalysis of transition metal complexes. Currently, the CPCs are received with different types of chirality [1]. The compounds of a variety of classes have been tested for their ability to become ligands for CPCs. However, the synthetic accessibility of chiral ligands remains an important problem.

\section{EXPERIMENTAL}

\subsection{General}

The ${ }^{1} \mathrm{H}$ and ${ }^{13} \mathrm{C}$ NMR spectra were recorded with a Bruker Avance-300 spectrometer operating at the frequencies 300 and $75 \mathrm{MHz}$ for ${ }^{1} \mathrm{H}$ and ${ }^{13} \mathrm{C}$ nucleus, respectively. The measurements were carried out at ambient temperature in $\mathrm{CDCl}_{3}$. Chloroform signals were used as an internal standard $\left(\delta_{\mathrm{H}} 7.27 \mathrm{ppm}, \delta_{\mathrm{C}} 77.00 \mathrm{ppm}\right)$. The assignment of signals was carried out using ${ }^{13} \mathrm{C}$ NMR spectra recorded in the mode of J-modulation, and according to two-dimensional correlation spectra of ${ }^{1} \mathrm{H}\left\{{ }^{1} \mathrm{H}\right\}$ (COSY) and ${ }^{1} \mathrm{H}\left\{{ }^{13} \mathrm{C}\right\}$ (HSQC) and NOE experiments. IR spectra were measured in a thin layer or in $\mathrm{KBr}$ pellets on a device "IR Prestige 21" made by Shimadzu. Optical rotations were measured on a Kruss P3002RS polarimeter (Germany) with a $10 \mathrm{~cm}$ cell and were reported as follows: $[\alpha]_{D}^{{ }^{\circ} \mathrm{C}}$ (concentration in $\mathrm{g} / 10 \mathrm{~mL}$, solvent). Elemental analyses were performed using an automatic analyzer EA 1110 CHNS-O.

All reactions were monitored on a thin layer chromatography (TLC) using Merck silica gel (70-230 mesh) and benzene acetone mixtures as eluents; the TLC spots were visualized with $\mathrm{J}_{2}$ and $\mathrm{KMnO}_{4} / \mathrm{H}_{2} \mathrm{SO}_{4}$. Column chromatography was carried out using Merck silica gel (70-230 mesh) and benzene acetone mixtures as eluents.

\subsection{Solvents and Starting Reagents}

Benzene was dried with $\mathrm{CaCl} 2$, refluxed with $\mathrm{Na}$, and then distilled from $\mathrm{Na}$. Methanol was distilled from MeONa. Hexane was distilled from Na. Palladium chloride was used without additional purification. (SC)- $\alpha$-Methylbenzylamine of $99 \%$ ee was purchased from Merck and used without purification. 
Imines HL1, HL3 and amines HL2, HL4 were prepared by a reported method [19].

\subsection{Di- $\mu-C h l o r o b i s\{(1 R, 2 R, 5 R)-3-$ (Benzylimino)-2,6,6-Trimethylbicyclo [3.1.1]Heptane-2-ol-C,N\} Dipalladium(II), 1}

A suspension of palladium chloride (II) $(0.09 \mathrm{~g}, 0.5$ $\mathrm{mmol})$ and lithium chloride $(0.04 \mathrm{~g}, 1.0 \mathrm{mmol})$ in methanol $(5 \mathrm{ml})$ was boiled in a water bath with a reflux condenser for one hour. The resulting solution of lithium tetrachloropalladate (dark-red color) added to a solution of imine $\mathrm{HL}^{1}(0.13 \mathrm{~g}, 0.5 \mathrm{mmol})$ and sodium acetate $(0.04 \mathrm{~g}, 0.5 \mathrm{mmol})$ in methanol $(5 \mathrm{ml})$. After stirring at room temperature for 1 hour the solvent was removed from the reaction mixture, the complex 1 was extracted with benzene $(3 \times 20 \mathrm{~mL})$. The crude product was purified using column chromatography on silica gel with benzene and benzene/acetone 10:1 mixture as eluents. After precipitation from benzene by hexane and drying in vacuum, complex 1 was obtained in the yield of $40 \%(0.080 \mathrm{~g}, \mathrm{mmol})$ as a yellow amorphous powder: $\mathrm{mp}(\mathrm{dec}) 166-167^{\circ} \mathrm{C}, \mathrm{R}_{\mathrm{f}} 0.71$ (5:1 benzene/acetone), $\lceil\alpha\rceil_{n}^{25}=-415.9\left(c 0.06, \mathrm{CHCl}_{3}\right)$.

IR, $v, \mathrm{~cm}^{-1}: 3441(\mathrm{OH}), 1618(\mathrm{C}=\mathrm{N}) .{ }^{1} \mathrm{H}$ NMR $\left(\mathrm{CDCl}_{3}, \delta /\right.$ ppm., $\left.J / \mathrm{Hz}\right): 0.73$ (s, $\left.3 \mathrm{H}, \mathrm{H}^{9}, \mathrm{Me}\right), 0.98$ (d, $1 \mathrm{H}, 7-\mathrm{H}_{\alpha}, J^{7 \alpha, 7 \beta} 11.0$ ), 1.10 (s, $3 \mathrm{H}, \mathrm{H}^{8}, \mathrm{Me}$ ), 2.12 (ddd, $\left.1 \mathrm{H}, 7-\mathrm{H}_{\beta}, J \quad 2.0, J 5.8, J^{7 \beta, 7 \alpha} 11.0\right), 2.26\left(\mathrm{~d}, 1 \mathrm{H}, \mathrm{H}^{4 \alpha}, J\right.$ $\left.{ }^{4 \alpha, 4 \beta} 18,3\right), 2.56\left(\mathrm{dd}, 1 \mathrm{H}, \mathrm{H}^{4 \beta}, J \quad 4.1, J^{4 \beta, 4 \alpha} 18.3\right.$ ), 2.94 (s, $\left.3 \mathrm{H}, \mathrm{H}^{10}, \mathrm{Me}\right), 4.22\left(\mathrm{~d}, 1 \mathrm{H}, \mathrm{H}^{11 \alpha}, J^{11 \alpha, 11 \beta} \quad 14.5\right), 4.47(\mathrm{~d}$, $\left.1 \mathrm{H}, \mathrm{H}^{11 \beta}, J^{11 \beta, 11 \alpha} 14.5\right), 7.15-7.45 \mathrm{~m}(4 \mathrm{H}$, arom. $) .{ }^{13} \mathrm{C}$ NMR $\left(\mathrm{CDCl}_{3}, \delta, \mathrm{ppm}\right): 23.27\left(\mathrm{C}^{9}\right), 26.88\left(\mathrm{C}^{8}\right), 28.18$ $\left(\mathrm{C}^{7}\right), 32.10\left(\mathrm{C}^{10}\right), 32.94\left(\mathrm{C}^{4}\right), 39.17\left(\mathrm{C}^{5}\right), 40.13\left(\mathrm{C}^{6}\right)$, $51.41\left(\mathrm{C}^{1}\right), 55.06\left(\mathrm{C}^{11}\right), 92.46\left(\mathrm{C}^{2}\right), 127.27\left(\mathrm{C}^{18}\right), 127.55$ $\left(\mathrm{C}^{17}\right), 128.33\left(\mathrm{C}^{16}\right), 128.57\left(\mathrm{C}^{14}\right), 128.85\left(\mathrm{C}^{15}\right), 135.24$ $\left(C^{13}\right), 197.63\left(C^{3}\right)$.

\subsection{Dichloro\{(1R,2R,5R)-3- (Benzylimino)-2,6,6-Trimethylbicyclo [3.1.1]Heptane-2-ol- N,N\}Palladium(II), 2}

A suspension of palladium chloride(II) $(0.04 \mathrm{~g}, 0.2$ $\mathrm{mmol})$ and lithium chloride $(0.02 \mathrm{~g}, 0.4 \mathrm{mmol})$ in methanol $(5 \mathrm{ml})$ was boiled in a water bath with a reflux condenser for one hour. The resulting solution of lithium tetrachloropalladate (dark-red) color was added to a solution of imine $\mathrm{HL}^{1}(0.1 \mathrm{~g}, 0.4 \mathrm{mmol})$ in methanol $(2 \mathrm{ml})$. After stirring at room temperature for $1 \mathrm{~h}$ the solvent was removed from the reaction mixture, the coordinated complex 2 was extracted with benzene $(3 \times 20 \mathrm{~mL})$. The crude product was purified using column chromatography on silica gel with benzene and benzene/acetone 10:1 mixture as eluents. After precipitation from benzene by hexane and drying in vacuum, complex 2 was obtained in the yield of $50 \%(0.070 \mathrm{~g}, \mathrm{mmol})$ as a yellow amorphous powder: $\mathrm{mp}(\mathrm{dec}) 153-154{ }^{\circ} \mathrm{C}, \mathrm{R}_{\mathrm{f}} 0.8$ (5:1 benzene/acetone), $[\alpha]_{D}^{25}=+113.5\left(c 0.07, \mathrm{CHCl}_{3}\right)$.

IR, v, $\mathrm{cm}^{-1}: 3410(\mathrm{OH}), 1612(\mathrm{C}=\mathrm{N}) .{ }^{1} \mathrm{H}$ NMR $\left(\mathrm{CDCl}_{3}, \delta /\right.$ ppm., $\left.J / \mathrm{Hz}\right): 0.75$ (s, 3H, $\left.\mathrm{H}^{9}, \mathrm{Me}\right), 1.22$ (s, $\left.3 \mathrm{H}, \mathrm{H}^{8}, \mathrm{Me}\right), 1.5\left(\mathrm{~d}, 1 \mathrm{H}, \mathrm{H}^{7 \alpha}, J^{7 \alpha, 7 \beta} 9.0\right), 1.8(\mathrm{~m}, 1 \mathrm{H}$, $\left.\mathrm{H}^{7 \beta}\right), 2.1\left(\mathrm{~m}, 1 \mathrm{H}, \mathrm{H}^{1}\right), 2.2\left(\mathrm{~m}, 2 \mathrm{H}, \mathrm{H}^{4}\right), 2.5\left(\mathrm{~m}, 1 \mathrm{H}, \mathrm{H}^{5}\right)$, $2.8\left(\mathrm{~s}, 3 \mathrm{H}, \mathrm{H}^{10}, \mathrm{Me}\right), 5.1\left(\mathrm{~d}, 1 \mathrm{H}, \mathrm{H}^{11 \alpha}, J^{11 \alpha, 11 \beta} 16.0\right), 5.9$ (d, $\left.1 \mathrm{H}, \mathrm{H}^{11 \beta}, J^{11 \beta, 11 \alpha} 16.0\right), 7.4$ (m, 5H, arom.). ${ }^{13} \mathrm{C} \mathrm{NMR}$ $\left(\mathrm{CDCl}_{3}, \delta, \mathrm{ppm}\right): 22.97\left(\mathrm{C}^{9}\right), 26.71\left(\mathrm{C}^{8}\right), 27.61\left(\mathrm{C}^{7}\right)$, $31.06\left(\mathrm{C}^{10}\right), 37.97\left(\mathrm{C}^{4}\right), 38.13\left(\mathrm{C}^{5}\right), 38.54\left(\mathrm{C}^{6}\right), 52.87$ $\left(\mathrm{C}^{1}\right), 63.00\left(\mathrm{C}^{11}\right), 76.61\left(\mathrm{C}^{2}\right), 127.21\left(\mathrm{C}^{15}\right), 127.55\left(\mathrm{C}^{16}\right)$, $128.83\left(\mathrm{C}^{14}\right), 133.81\left(\mathrm{C}^{13}\right), 192.35\left(\mathrm{C}^{3}\right)$.

\subsection{Dichloro\{(1S,2S,3S,5S)-3- (Benzylamino)-2,6,6- Trimethylbicyclo [3.1.1]Heptane-2-ol-N,N\} Palladium(II), 3}

A suspension of palladium chloride(II) $(0.04 \mathrm{~g}, 0.2$ $\mathrm{mmol})$ and lithium chloride $(0.02 \mathrm{~g}, 0.4 \mathrm{mmol})$ in methanol $(5 \mathrm{ml})$ was boiled in a water bath with a reflux condenser for one hour. The resulting solution of lithium tetrachloropalladate (dark-red color) was added to a solution of imine HL2 $(0.12 \mathrm{~g}, 0.4 \mathrm{mmol})$ in methanol $(2 \mathrm{ml})$. After stirring at room temperature for $1 \mathrm{~h}$ the solvent was removed from the reaction mixture, the coordinated complex 3 was extracted with benzene $(3 \times 20 \mathrm{~mL})$. The crude product was purified using column chromatography on silica gel with benzene and benzene/acetone 10:1 mixture as eluents. After precipitation from benzene by hexane and drying in vacuum, complex 3 was obtained in the yield of $60 \%(0.085 \mathrm{~g}, \mathrm{mmol})$ as a yellow amorphous powder: $\mathrm{mp}(\mathrm{dec}) 167-168^{\circ} \mathrm{C}, \mathrm{R}_{\mathrm{f}} 0.85$ (5:1 benzene/acetone), $[\alpha]_{n}^{25}=-62.6\left(c 0.09, \mathrm{CHCl}_{3}\right)$.

IR, $v, \mathrm{~cm}^{-1}: 3479(\mathrm{OH}), 3253(\mathrm{NH}) .{ }^{1} \mathrm{H}$ NMR $\left(\mathrm{CDCl}_{3}\right.$, $\delta / \mathrm{ppm} ., J / \mathrm{Hz}): 0.75$ (s, 3H, H $\left.\mathrm{H}^{9}, \mathrm{Me}\right), 1.24\left(\mathrm{~s}, 3 \mathrm{H}, \mathrm{H}^{8}\right.$, $\mathrm{Me}), 1.43\left(\mathrm{~s}, 3 \mathrm{H}, \mathrm{H}^{10}, \mathrm{Me}\right), 1.46\left(\mathrm{~d}, 1 \mathrm{H}, \mathrm{H}^{7 \alpha}, J^{7 \alpha, 7 \mathrm{\beta}} 11.0\right)$, 1.73-1.81 (m, $\left.2 \mathrm{H}, \mathrm{H}^{1}, \mathrm{H}^{5}\right), 1.88\left(\mathrm{dd}, 1 \mathrm{H}, \mathrm{H}^{4 \alpha}, J^{4 \alpha, 3} 10.0\right.$, $\left.J^{4 \alpha, 4 \beta} 14.1\right), 2.10 \mathrm{ddd}\left(1 \mathrm{H}, \mathrm{H}^{7 \beta}, J 5.7, J 6.1, J^{7 \beta, 7 \alpha} 11.0\right)$, 2.61 (ddd, $\left.1 \mathrm{H}, \mathrm{H}^{4 \beta}, J \quad 4.9, J^{4 \beta, 3} 9.8, J^{4 \beta, 4 \alpha} 14.1\right), 3.08$ $\left(\mathrm{dd}, 1 \mathrm{H}, \mathrm{H}^{3}, J^{3,4 \beta} 9.8, J^{3,4 \alpha} 10.0\right), 4.04 \mathrm{~m}(2 \mathrm{H}, \mathrm{H}(11))$, $7.33\left(\mathrm{~d}, 1 \mathrm{H}, \mathrm{H}^{16}, J^{16,15} 7.0\right), 7.40\left(\mathrm{dd}, 2 \mathrm{H}, \mathrm{H}^{15}, J^{15,16} 7.0\right.$, $J^{15,14}$ 7.6), $7.50\left(\mathrm{~d}, 2 \mathrm{H}, \mathrm{H}^{14}, J^{14,15}\right.$ 7.6). ${ }^{13} \mathrm{C}$ NMR $\left(\mathrm{CDCl}_{3}, \delta / \mathrm{ppm}.\right): 23.22\left(\mathrm{C}^{9}\right), 23.39\left(\mathrm{C}^{10}\right), 24.05\left(\mathrm{C}^{7}\right)$, $27.54\left(\mathrm{C}^{8}\right), 32.14\left(\mathrm{C}^{4}\right), 39.48\left(\mathrm{C}^{6}\right), 40.58\left(\mathrm{C}^{5}\right), 57.13\left(\mathrm{C}^{1}\right)$, $57.55\left(\mathrm{C}^{11}\right), 65.18\left(\mathrm{C}^{3}\right), 76.60\left(\mathrm{C}^{2}\right), 127.74\left(\mathrm{C}^{16}\right), 128.38$ $\left(\mathrm{C}^{15}\right), 129.90\left(\mathrm{C}^{14}\right), 135.53\left(\mathrm{C}^{13}\right)$. 


\subsection{Di- $\mu-C h l o r o b i s\{(1 R, 2 R, 5 R)-3-((1 S)-$ a-Methylbenzylimino)-2,6,6- Trimethylbicyclo[3.1.1] Heptane-2-ol-C,N\}Dipalladium(II), 4}

Synthesis is carried out similarly to that described for (1). Dimer 4 as a yellow amorphous powder, yield $50 \%(0.103 \mathrm{~g}, \mathrm{mmol}), \mathrm{mp}(\mathrm{dec}) 145-146{ }^{\circ} \mathrm{C}$, Rf 0.4 (5:1 benzene/acetone), $[\alpha]_{D}^{25}=-32.0$ (c 0.08 , aceton).

IR, v, cm-1: $3337(\mathrm{OH}), 1631(\mathrm{C}=\mathrm{N}) .1 \mathrm{H}$ NMR (CDCl3, $\delta$ / ppm., J / Hz): 0.99 (s, 3H, H9, Me), 1.29 (d, 3H, H12, Me, J 12,11 6.8), 1.39 (s, 3H, H8, Me), $1.91(\mathrm{~d}, 1 \mathrm{H}, \mathrm{H} 7 \alpha, \mathrm{J} 7 \alpha, 7 \beta$ 11.8), 1.95 (s, 3H, H10, Me), 2.12 (m, 1H, H5, J 5,1 5.5 ), 2.27 (m, 1H, H1, J 1,5 5.5, J 5.5), 2.59 (m, $2 \mathrm{H}, \mathrm{H} 4 \alpha, \mathrm{H} 7 \beta)$, J 3.9, J $4 \beta, 4 \alpha$ 18.3 ), 2.73 (dd, $1 \mathrm{H}, \mathrm{H} 4 \beta, \mathrm{J} \quad 3.9, \mathrm{~J} 4 \beta, 4 \alpha 18.3$ ), 4.05 (sq, 1H, H11, J 11,12 6.8), 6.57 (d, 1H, H18, J 18,17 7.6), 6.84 (dd, 1H, H17, J 17,18 7.6, J 17,16 8.0), 7.04 (dd, 1H, H16, J 16,17 8.0, J 16,15 8.0), $7.44(\mathrm{~d}, 1 \mathrm{H}$, $\mathrm{H} 15$, J 15,16 8.0). 13C NMR ( $\left.\mathrm{CDCl}_{3}, \delta, \mathrm{ppm}\right): 22.43$ $\left(\mathrm{C}^{12}\right), 23.18\left(\mathrm{C}^{9}\right), 27.23\left(\mathrm{C}^{8}\right), 27.90\left(\mathrm{C}^{10}\right), 28.87\left(\mathrm{C}^{7}\right)$, $33.90\left(\mathrm{C}^{4}\right), 38.41\left(\mathrm{C}^{5}\right), 40.52\left(\mathrm{C}^{6}\right), 51.78\left(\mathrm{C}^{1}\right), 67.00$ $\left.\left(\mathrm{C}^{11}\right), 88.64\left(\mathrm{C}^{2}\right)\right), 122.33\left(\mathrm{C}^{18}\right), 124.61\left(\mathrm{C}^{16}\right), 124.75$ $\left(\mathrm{C}^{17}\right), 135.51\left(\mathrm{C}^{15}\right), 138.84\left(\mathrm{C}^{13}\right), 156.52\left(\mathrm{C}^{14}\right), 185.10$ $\left(\mathrm{C}^{3}\right)$.

\subsection{Di- $\mu-C h l o r o b i s\{(1 R, 2 R, 3 R, 5 R)-3-$ ((S)- $\alpha$-Methylbenzylamino)-2,6,6- Trimethylbicyclo[3.1.1] Heptane-2-ol-C,N\}Dipalladium(II), 5}

Synthesis is carried out similarly to that described for (1). Dimer 5 as a yellow amorphous powder, yield $55 \%$ (0.114 g, mmol), mp (dec) $169-170{ }^{\circ} \mathrm{C}$, Rf 0.3 (5:1 benzene/acetone), $[\alpha]_{D}^{25}=+19.7$ (c 0.04 , $\mathrm{CHCl} 3)$.

IR, v, cm-1: $3421(\mathrm{OH}), 3217(\mathrm{NH})$. 1H NMR (CDCl3, $\delta$ / ppm., J / Hz): 0.96 (s, 3H, H9, Me), 1.29 (s, 3H, H8, Me), 1.56 (s, 3H, H10, Me), $1.66(\mathrm{dd}, 1 \mathrm{H}$, $\mathrm{H} 4 \alpha, \mathrm{J} 4 \alpha, 3$ 11.3, J $4 \alpha, 4 \beta$ 13.9), 1.75 (d, $1 \mathrm{H}, \mathrm{H} 7 \alpha, \mathrm{J}$ $7 \alpha, 7 \beta$ 10.9), 1.81 (d, 3H, H12, J 12,11 6.4), 1.95 (m, $1 \mathrm{H}, \mathrm{H} 1, \mathrm{~J} 1,7 \beta$ 5.6), $2.01(\mathrm{~m}, 1 \mathrm{H}, \mathrm{H} 5), 2.17(\mathrm{dd}, 1 \mathrm{H}$, H7 $\beta$, J 7 $\beta, 1$ 5.6, J 7 $\beta, 7 \alpha$ 10.9), 2.46 (s, OH), 2.56 (ddd, $1 \mathrm{H}, \mathrm{H} 4 \beta, \mathrm{J} 5.6, \mathrm{~J} 4 \beta, 3$ 9.0, J $4 \beta, 4 \alpha$ 13.9), 4.14 (sq, $1 \mathrm{H}$,

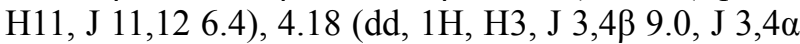
11.3), 4.40 (s, NH)), 6.74 (dd, 1H, H18, J 18,16 1.3, J 18,17 7.2), 6.87 (ddd, 1H, H16, J 16,181.3, J 16,17 7.3, J 16,15 8.5), 6.96 (dd, 1H, H17, J 17,18 7.2, J 17,16 7.3), 7.24 (d, 1H, H15, J 15,16 8.5). 13C NMR (CDCl3, $\delta$, ppm): 22.89 (C9), 24.02 (C7), 24.24 (C10), $25.88\left(\mathrm{C}^{12}\right), 28.05\left(\mathrm{C}^{8}\right), 28.48\left(\mathrm{C}^{4}\right), 40.16\left(\mathrm{C}^{6}\right), 40.62$ $\left(\mathrm{C}^{5}\right), 55.47\left(\mathrm{C}^{1}\right), 64.39\left(\mathrm{C}^{11}\right), 67.51\left(\mathrm{C}^{3}\right), 77.55\left(\mathrm{C}^{2}\right)$, $119.89\left(\mathrm{C}^{18}\right), 124.79\left(\mathrm{C}^{17}\right), 125.10\left(\mathrm{C}^{16}\right), 134.01\left(\mathrm{C}^{15}\right)$,
$141.92\left(\mathrm{C}^{13}\right), 156.95\left(\mathrm{C}^{14}\right)$.

\section{RESULTS AND DISCUSSION}

Earlier, we reported on the synthesis of chiral imines and amines on the basis of $2 \alpha$-hydroxypinan-3-one [19]. These ligands, containing in its composition benzylamine fragment, are of interest from the standpoint of the possibility of obtaining ortho-palladated complexes. In the present work we investigated the interaction of the obtained ligands $\mathbf{H L}^{1}, \mathbf{H L}^{2}, \mathbf{H L}^{3}, \mathbf{H L}^{4}$ with lithium tetrachloropalladate $\left(\mathrm{Li}_{2} \mathrm{PdCl}_{4}\right)$ in the method of Cope [20]. Reaction of cyclopalladation is accompanied by the release of hydrogen chloride. An insertion of an additional base is necessary for the neutralization of the hydrogen chloride.

The structure of obtained complex compounds is confirmed by NMR, IR spectroscopy and elemental analysis data, last are given in Table 1 .

On the basis of imine $\mathbf{H L}^{1}$ we managed to get binuclear palladacycle 1 with the yield of $40 \%$ in the presence of sodium acetate as base at a molar ratio of reagents 1:1. In the absence of the base at a molar ratio of reagents 1:2 mononuclear coordinated complex 2 was obtained in 50\% yield (Scheme 1). Complex compounds 1 and $\mathbf{2}$ were isolated from the reaction mixture by column chromatography and further purified by crystallization from a mixture of benzene-hexane.

The signals of protons of methylene group $-\mathrm{CH}_{2} \mathrm{~N}=$ were observed in the ${ }^{1} \mathrm{H}$ NMR spectrum of compound $\mathbf{1}$ in the form of two doublets with geminal constant of $14.5 \mathrm{~Hz}$ (two-proton singlet was observed in the spectrum of the initial ligand), which confirms the formation of the cycle. The change of the multiplicity and the integrated intensity of signals of protons of benzene ring corresponds to the ortho-disubstituted ring. The preservation of the multiplicity and the integral intensity of proton signals of the monosubstituted benzene ring in the ${ }^{1} \mathrm{H}$ NMR spectrum of compound 2 excludes ortho-palladation.

In contrast to the corresponding imine $\mathbf{H L}^{\mathbf{1}}$ amine $\mathbf{H L}^{2}$ forms only mononuclear coordinated complex 3 even in the presence of a base (AcONa) (Scheme 2). This result can be explained by the fact that the secondary amino group exhibits stronger electron donor properties than the imine, and reduces the electrophilic activity of palladium, preventing the ortho-palladation.

The interaction of amine $\mathbf{H L}^{2}$ with $\mathrm{Li}_{2} \mathrm{PdCl}_{4}$ may form a mixture of diastereomeric complexes in which the configuration of tetragonal nitrogen atom consolidates with the metal and the nitrogen becomes an additional center of chirality. There is only one set of signals in the ${ }^{1} \mathrm{H}$ NMR spectrum of compound 3 that indicates the forma- 
Table 1. The analytical data for the complexes.

\begin{tabular}{|c|c|c|c|c|c|c|c|}
\hline \multirow[t]{2}{*}{ №. } & \multirow[t]{2}{*}{ Complex } & \multirow{2}{*}{$\begin{array}{c}\text { Color } \\
\text { [Empirical formula] } \\
\text { (Formula weight) }\end{array}$} & \multicolumn{5}{|c|}{$\begin{array}{l}\text { Analytical Data } \\
\qquad \% \text { Found (Calculated) }\end{array}$} \\
\hline & & & & & $\mathrm{C}$ & $\mathrm{H}$ & $\mathrm{N}$ \\
\hline 1 & $\mathrm{C} 34 \mathrm{H} 44 \mathrm{~N} 2 \mathrm{O} 2 \mathrm{Pd} 2 \mathrm{Cl} 2$ & $\begin{array}{l}\text { yellow } \\
\quad(795.75)\end{array}$ & 51.8 & 5.67 & $\begin{array}{l}3.2 \\
(51.3)\end{array}$ & (5.53) & (3.5) \\
\hline 2 & $\mathrm{C} 34 \mathrm{H} 46 \mathrm{~N} 2 \mathrm{O} 2 \mathrm{PdCl} 2$ & $\begin{array}{l}\text { yellow } \\
\qquad(691.37)\end{array}$ & 57.2 & 6.62 & $\begin{array}{l}3.9 \\
(59.1)\end{array}$ & $(6.65)$ & $(4.0)$ \\
\hline 3 & $\mathrm{C} 34 \mathrm{H} 50 \mathrm{~N} 2 \mathrm{O} 2 \mathrm{PdCl} 2$ & $\begin{array}{l}\text { yellow } \\
\quad(695.36)\end{array}$ & 58.7 & 7.31 & $\begin{array}{l}3.90 \\
(58.7)\end{array}$ & $(7.20)$ & $(4.03)$ \\
\hline 4 & $\mathrm{C} 36 \mathrm{H} 48 \mathrm{~N} 2 \mathrm{O} 2 \mathrm{Pd} 2 \mathrm{Cl} 2$ & $\begin{array}{l}\text { yellow } \\
\qquad(823.77)\end{array}$ & 52.6 & 5.93 & $\begin{array}{l}3.3 \\
(52.4)\end{array}$ & $(5.93)$ & (3.3) \\
\hline 5 & $\mathrm{C} 36 \mathrm{H} 52 \mathrm{~N} 2 \mathrm{O} 2 \mathrm{Pd} 2 \mathrm{Cl} 2$ & $\begin{array}{l}\text { yellow } \\
\quad(827.76)\end{array}$ & 52.4 & 6.21 & $\begin{array}{l}3.21 \\
(52.2)\end{array}$ & $(6.28)$ & (3.30) \\
\hline
\end{tabular}

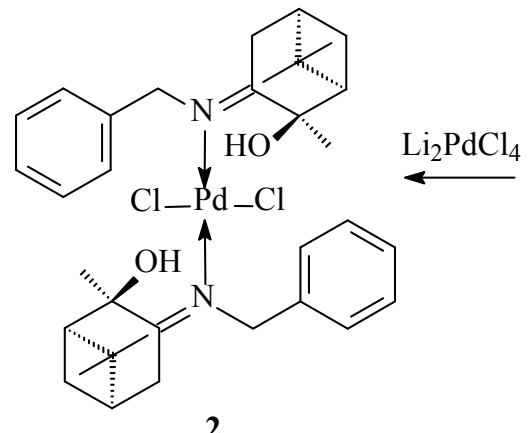

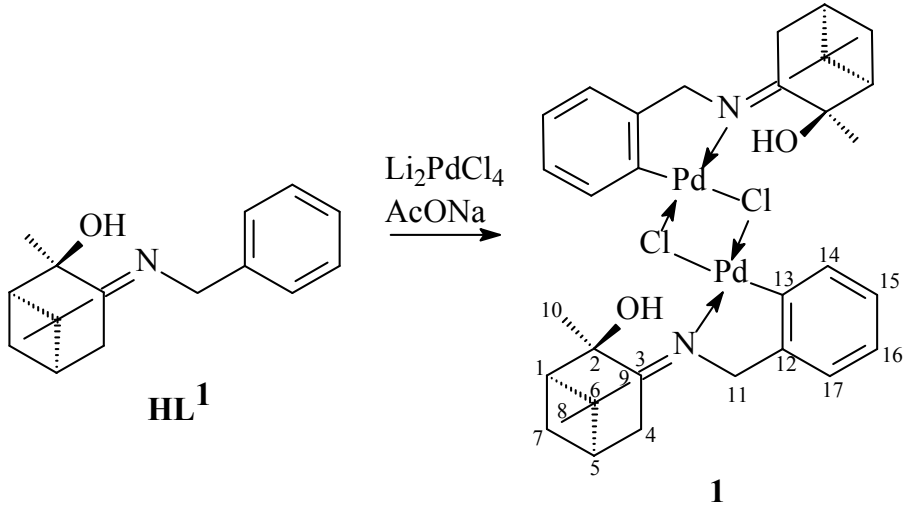

Scheme 1

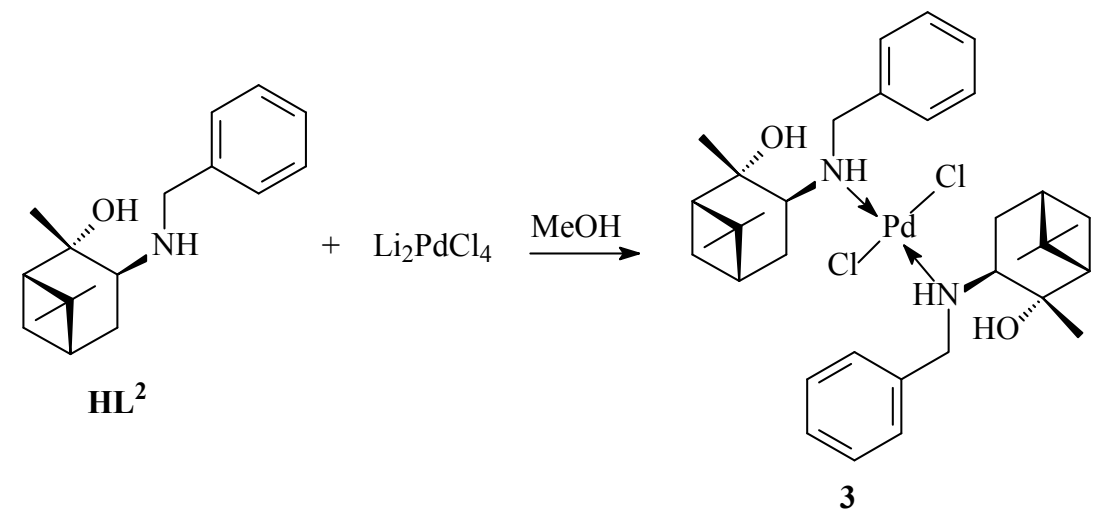

Scheme 2

tion of one of the possible diastereomers. Multiplicity and integral intensity of proton signals corresponds to the monosubstituted benzene ring.

The interaction of imine $\mathbf{H L}^{3}$ and amine $\mathbf{H L}^{4}$, containing $\alpha$-methylbenzylamine fragment with lithium tetrachloropalladate was investigated under the specified above conditions. It was found that the imine $\mathbf{H L}^{3}$ exposed cyclopalladation even in the absence of a base. Binuclear palladacycle 4 was obtained in the presence of sodium acetate at a molar ratio of reagents 1:1 and in the absence of sodium acetate at a molar ratio of reagents 1:2 (Scheme 3). This result is quite understandable giv- en the fact that the second molecule of imine can serve as a base, binding hydrogen chloride, thereby stimulating cyclometallation.

Unlike amine $\mathbf{H L}^{2}$, that forms only the coordinated complex in the investigated conditions, amine $\mathbf{H L}^{4}$, that contains a methyl group in $\alpha$-position, reacts with lithium tetrachloropalladate in the presence of sodium acetate at a molar ratio of reagents 1:1 to form a binuclear palladacycle 5 with yield 55\% (Scheme 4). A mixture of two complex compounds - coordinated and palladacycle are formed in the absence of sodium acetate at a molar ratio of reagents $1: 2$, which was is confirmed by ${ }^{1} \mathrm{H}$ 


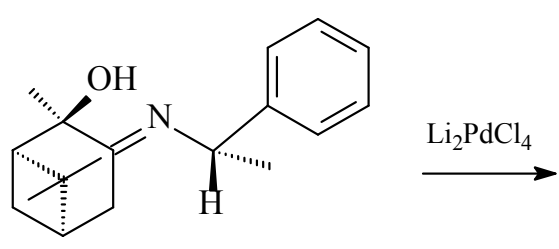

$\mathbf{H L}^{3}$

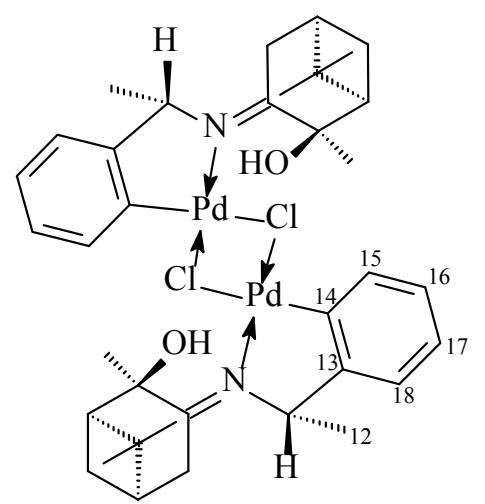

4

Scheme 3<smiles>C[C@H](N[C@@]12C[C@H]3C[C@@H](C1(C)O)C32C)c1ccccc1</smiles>

$\mathrm{HL}^{4}$

Scheme 4

NMR and ${ }^{13} \mathrm{C}$ spectroscopy.

The formation of ortho-palladated complexes $\mathbf{4}$ and $\mathbf{5}$ is confirmed by NMR spectra: there are four nonequivalent signals of aromatic protons in the ${ }^{1} \mathrm{H}$ spectra with a particular splitting (two doublets and two doublets of doublets) and four aromatic methine groups in the ${ }^{13} \mathrm{C}$ spectra. All set of signals of terpene fragments remains in the spectra. A slight shift is reported (compared to the ligands) for nucleis located close to palladium. One set of signals in the spectra of the complexes 4 and 5 is observed which indicates the symmetry of the complexes.

The ease of the cyclopalladation of the $\alpha$-methylbenzilamine derivatives $\mathbf{H L}^{3}$ and $\mathbf{H L}^{4}$ once again underlines the role of spatial factors in reactions of the metallocycles formation.

\section{CONCLUSIONS}

Mononuclear coordination complexes - (HL1)2PdCl2 (2), (HL2)2 $\mathrm{PdCl} 2$ (3) and palladacycle dimers $\mathrm{PdL} 1 \mathrm{Cl}$ (1), PdL3Cl (4), PdL4Cl (5) have been iso- lated separately, the structure of which was studied and confirmed by spectral methods and by elemental analysis

\section{REFERENCES}

[1] Dupont, J., Consorti, C.S. and Spencer, J. (2005) The potential of palladacycles: More than just precatalysts. Chemical Reviews, 105, 2527-2571.

[2] Loh, S.K., Vittal, J.J. and Leung, P.H. (1998) 1-Methyl-2-vinylpyrrole and 1-phenyl-3,4-dimethylphosphole: Their coordination chemistries and reactivities in a chiral palladium complex promoted asymmetric $\mathrm{Di}$ els-Alder reaction. Tetrahedron: Asymmetry, 9, 423- 428.

[3] Ding, Y., Li, Y., Zhang, Y., Pullarkat, S.A. and Leung, P.H. (2008) Design, synthesis and stereochemical evaluation of a novel chiral amine-palladacycle. European Journal of Inorganic Chemistry, 2008, 1880-1891.

[4] Gugger, P.A.,Willis, A.C., Wild, S.B., Heath, G.A., Webster, R.D. and Nelson, J.H. (2002) Enantioselective synthesis of a conformationally rigid, sterically encumbered, 2-arsino-7-phosphanorbornene. The Journal of $\mathrm{Or}$ ganometallic Chemistry, 643, 136-153.

[5] Zhao, V. I. (1999) Insertion reaction between planar chiral 
cyclopalladated derivatives of ferrocene and diphenylacetylene. The Journal of Organometallic Chemistry, 574, 311-317.

[6] Sokolov, V.I. (1995) Optically active organometallic compounds (a personal account from the inside). The Journal of Organometallic Chemistry, 500, 299- 306.

[7] Spencer, J. and Pfeffer, M. (1995) The fate of the stereogenic centre linked to palladium upon reaction with an alkyne. Tetrahedron: Asymmetry, 6, 419-426.

[8] Hollis, T.K. and Overman, L.E. (1997) Cyclopalladated ferrocenyl amines as enantioselective catalysts for the rearrangement of allylic imidates to allylic amides. Tetrahedron Letters, 38, 8837-8840.

[9] Chahen, L., Therrien, B. and Suss-Fink, G. (2007) Square-planar diacetatopalladium complexes with transconfigured secondary amine ligands that avoid orthometalation: ligand synthesis, coordination, molecular structure and catalytic potential for suzuki cross-coupling reactions. European Journal of Inorganic Chemistry, 2007, 5045-5051.

[10] Zalevskaya, O.A., Vorob'eva, E.G., Dvornikova, I.A. and Kuchin, A.V. (2008) Palladium complexes based on optically active terpene derivatives of ethylenediamine. Russian Journal of Coordination Chemistry, 34, 855857.

[11] Overman, L.E. and Remarchuk, T.P. (2000) Catalytic asymmetric intramolecular aminopalladation: enantioselective synthesis of vinyl-substituted 2-oxazoli dinones, 2-imidazolidinones, and 2-pyrrolidinones. Journal of American Chemical Society, 124, 12-13.

[12] Kirsch, S.F. and Overman, L.E. (2005) Catalytic asymmetric synthesis of chiral allylic esters. Journal of American Chemical Society, 127, 2866-2867.

[13] Levrat, F., Stoeckli-Evans, H. and Engel, N. (2002) Enantiomeric excess determination of $\alpha$-amino acids by
${ }^{19} \mathrm{~F}$ NMR spectroscopy of their N,N-dimethyl-(2,2,2trifluoro-1-phenylethyl)amine-C,N)palladium complexes. Tetrahedron: Asymmetry, 13, 2335-2344.

[14] Dunina, V. V., Kuz'mina, L. G., Kazakova, M.Y., Grishin, Y.K., Veits, Y.A. and Kazakova, E.I. (1997) Ortho-palladated $\alpha$-phenylalkylamines for enantiomeric purity determination of monodentate $\mathrm{P} *$-chiral phosphines, Tetrahedron: Asymmetry, 8, 2537-2545.

[15] Albert, J., Granell, J., Muller, G., Sainz, D., Font-Bardia, M. and Solans, X. (1995) Chiral Cyclopalladated compounds for enantiomeric purities of functionalized phosphines by means of multinuclear NMR. Tetrahedron: Asymmetry, 6, 325.

[16] Ding, Y., Chiang, M., Pullarkat, S.A., Li, Y. and Leung, P.H. (2009) Synthesis, coordination characteristics, conformational behavior and bond reactivity studies of a novel chiral phosphapalladacycle complex. Organometallics, 28, 4358-4370.

[17] Albert, J., Cadena, J.M., Delgado, S. and Granell, J. (2000) Synthesis and resolution of a new P-chiral hydroxy phosphine. The Journal of Organometallic Chemistry, 603, 235-239.

[18] Dunina, V.V., Kuz'mina, L.G., Rubina, M.Y., Grishin, Y.K., Veits, Y.A. and Kazakova, E.I. (1999) A resolution of the monodentate $\mathrm{P}^{*}$-chiral phosphine $\mathrm{PBU}(\mathrm{t}) \mathrm{C}_{6} \mathrm{H}_{4} \mathrm{Br}-4$ and its NMR-deduced absolute configuration. Tetrahedron: Asymmetry, 10, 1483-1497.

[19] Gur'eva, Y.A., Zalevskaya, O.A., Frolova, L.L., Alexeev, I.N. and Kutchin, A.V. Chiral imines and amines on the basis of 2 $\alpha$-hydroxypinan-3-one. Chemistry of Natural Compounds, in press.

[20] Cope, A.C. and Siekman, R.W. (1965) Formation of covalent bonds from platinum or palladium to carbon by direct substitution. Journal of American Chemical Society, 87, 3272-3273. 